\title{
A Note on Conventions
}

The terms "Hebrew Bible" and "Old Testament" are used interchangeably. While Jews would not regard the Hebrew scriptures as the "Old Testament," Christians have traditionally done so, and both designations will be used.

Arabic transliteration is normally given in full, according to the system of the International Journal of Middle East Studies. However, some Arabic words which have become common in English usage are not transliterated, or not fully transliterated, for example, Qur'an, hadith, Sunni and Shia. Muhammad is likewise not fully transliterated, unless it occurs as part of an otherwise fully transliterated name of an author.

In the main text titles of works are given first in English, to enhance readability, then in their original language. In references, the original language title is employed, with the translation also given for texts not already mentioned in the main text. In this, and in providing references to translations and reference articles as needed, I have sought to make this book accessible to those from a Biblical studies background who may be unfamiliar with the terrain of Islamic studies.

Dates involving Muslim people or events are given in $\mathrm{AH} / \mathrm{CE}$ format. Other dates are given in CE format.

Translations of the Bible are taken from the New Revised Standard Version. Translations of the Qur'an are taken from A.J. Droge, The Qur'ān: a New Annotated Translation (Sheffield: Equinox, 2013, reprinted with corrections 2017). 
